\title{
Phytoplankton assemblage changes during decadal decreases in nitrogen loadings to the urbanized Long Island Sound estuary, USA
}

\author{
Elizabeth A. Suter ${ }^{1, *}$, Kamazima M. M. Lwiza ${ }^{1}$, Julie M. Rose ${ }^{2}$, Christopher Gobler $^{1}$, \\ Gordon T. Taylor ${ }^{1}$
}

${ }^{1}$ School of Marine \& Atmospheric Sciences, Stony Brook University, Stony Brook, New York 11794-5000, USA
${ }^{2}$ NOAA Fisheries, Northeast Fisheries Science Center, Milford Laboratory, Milford, Connecticut 06460, USA

ABSTRACT: Despite reductions in nitrogen loadings from wastewater treatment plants (WWTPs) discharging into Long Island Sound (LIS) over the last $15 \mathrm{yr}$, eutrophication and hypoxia remain a severe problem. Here we used time series of hydrography, meteorology, nutrients, and phytoplankton pigments to explore the relationships between planktonic biomass, nutrient stocks, and physical regimes in LIS. With the exception of the most eutrophied station in the west, dissolved inorganic nitrogen (DIN) decreased between 1995 and 2009, likely resulting from WWTP upgrades. However, total dissolved nitrogen increased during this period, primarily driven by rising organic nitrogen pools. Simultaneous increases in inorganic phosphorus, silicate, and chlorophyll a (chl a) were also observed. Starting in 2002, pigment-based phytoplankton community composition revealed systematic declines in diatom abundances coincident with increases in dinoflagellates and other flagellated phytoplankton groups. Despite this, bottom water dissolved oxygen concentrations did not improve. The apparent paradox between increasing DIN limitation and escalating chl a concentrations in LIS suggests a shifting nutrient stoichiometry and an altered phytoplankton community in which phytoflagellates have increased in abundance relative to diatoms. Despite these changes, diatoms remained the most abundant algal group by the end of the study. In addition, a shift in chl a stocks in the year 2000 coincided with decreases in temperature, increases in salinity, and the proliferation of several algal groups. These results reveal the complex nature of eutrophied estuaries and indicate that policies targeting only inorganic nitrogen loadings may be insufficient to mitigate eutrophication in systems such as LIS.

KEY WORDS: Nitrogen limitation $\cdot$ Nutrients $\cdot$ Eutrophication $\cdot$ Phytoplankton $\cdot$ Nutrient ratio $\cdot$ Hypoxia Resale or republication not permitted without written consent of the publisher

\section{INTRODUCTION}

Anthropogenic eutrophication of estuaries has long been recognized as a significant ecological problem (Nixon 1995, Howarth \& Marino 2006). Nutrients from agriculture, wastewater treatment facilities, urban runoff, and septic systems can stimulate phytoplankton blooms, which sink and enhance biological oxygen demand in deeper waters (Smith et al. 2003, Diaz \& Rosenberg 2008). Without physical ventilation, water at depth becomes hypoxic or even anoxic, spatially compressing habitats for aerobic organisms, including commercially important finfish and shellfish (Howell \& Simpson 1994). Coastal eutrophication is a global concern, and many estuaries, such as Chesapeake Bay, San Francisco Bay, and those of the Delaware, Neuse, Seine, and St. Lawrence Rivers, suffer from seasonal hypoxia linked to anthropogenic nutrient loadings (Diaz \& Rosenberg 2008). 
Primary productivity is frequently limited by the availability of inorganic nutrients. In the 1970 s, studies revealed that phosphorus (P) runoff was the primary cause of eutrophication in lakes, and legislation limiting $\mathrm{P}$ loads soon followed (Howarth \& Marino 2006). More recently, scientists and managers identified nitrogen $(\mathrm{N})$ as the primary limiting factor for phytoplankton growth in the coastal and estuarine environment, and concluded that reductions in total $\mathrm{N}$ loadings were needed to control phytoplankton blooms (Nixon 1995, Cloern 2001). Since then, N loadings have been the main target of legislation aimed at reducing eutrophication in estuaries (Howarth \& Marino 2006). Recent publications have recommended the inclusion of $\mathrm{P}$ in coastal and estuarine management programs in addition to $\mathrm{N}$ (Howarth \& Marino 2006, Conley et al. 2009). Other factors such as water turbidity, the distribution of plants and macroalgae, sediment chemistry, nutrient cycling, and nutrient ratios have also been identified as important factors controlling eutrophication (Cloern 2001).

Selective nutrient abatement can change nutrient ratios, which has important consequences for a planktonic community. For example, as $\mathrm{N}$ loadings decline, silica:N (Si:N) ratios should increase, favoring diatoms over other phytoplankton taxa (Cloern 2001). However, at low dissolved inorganic N (DIN) concentrations, smaller cells should proliferate because of the ability of many small taxa to outcompete larger cells at low resource concentrations (Sunda \& Hardison 2007).

Long Island Sound (LIS), USA, located between Long Island, New York (NY), and Connecticut's (CT) south shore, has experienced eutrophication and seasonal hypoxia since at least the 1970s (Parker \& O'Reilly 1991). Eutrophication and hypoxia are typically most severe in western LIS due to its proximity to New York City (NYC; Anderson \& Taylor 2001) and the long hydraulic residence times within the estuary (63 to $160 \mathrm{~d}$; Turekian et al. 1996). In 1985, a partnership between the US Environmental Protection Agency (USEPA) and the states of NY and CT formed the Long Island Sound Study (LISS) in order to increase efforts and collaboration among the 2 states and a variety of federal, state, and local partners to restore and protect LIS. One of the many goals of the program included a reduction in $\mathrm{N}$ loadings to LIS, primarily through upgrades to wastewater treatment plants (WWTPs) (NYSDEC \& CTDEEP 2000). LISS also funds the Connecticut Department of Energy and Environmental Protection (CTDEEP) to manage a water quality monitoring pro- gram in which more than 40 stations are sampled on a monthly basis. Based on early findings, a total maximum daily load was approved for N in LIS in 2000, with the goal to reduce anthropogenic $\mathrm{N}$ loadings by $58.5 \%$ by 2014 (NYSDEC \& CTDEEP 2000). By 2010, primarily through upgrades to WWTPs but also through an increasing number of projects targeting nonpoint sources of $\mathrm{N}, 70 \%$ of this goal had been achieved (41\% total reduction; LISS 2011). By limiting $N$, the LISS and managers hoped to decrease the frequency and intensity of phytoplankton blooms, and the subsequent sinking and delivery of hypoxiafueling organic matter to depth. However, despite the successful reduction of $\mathrm{N}$ loadings to the estuary, eutrophication-driven hypoxia continues to be a significant problem (LISS 2011).

LIS is not unique in that the implementation of $\mathrm{N}$ source control programs has not mitigated eutrophication and hypoxia to any perceptible degree (Lee \& Lwiza 2008, Kemp et al. 2009). The comparison of eutrophic estuaries worldwide has shown that the efficacy of $\mathrm{N}$ source reduction efforts has varied widely at the ecosystem scale (Cloern 2001). Here we aimed to identify the impact of the ongoing implementation of $\mathrm{N}$ reductions on water quality in LIS over a 15 yr period by identifying changes in nutrient concentrations, stoichiometry, phytoplankton biomass and community structure, and hydrographic forcings that have occurred since $\mathrm{N}$ reductions began in the early 1990 s.

\section{MATERIALS AND METHODS}

\section{Biogeochemical and physical data}

Annual rates of $\mathrm{N}$ discharge from all WWTPs into LIS were obtained from the NY State Department of Environmental Conservation (NYSDEC). Only annual discharge rates are available, and therefore variability in $\mathrm{N}$ discharge could not be compared to monthly fluctuations in other variables. In addition, annual $\mathrm{N}$ and P discharge from all NYC WWTPs discharging into western LIS were obtained from the Interstate Environmental Commission for New York, New Jersey, and Connecticut. Water column nutrient concentrations, chlorophyll a (chl a), $\mathrm{O}_{2}$, and hydrographic data were obtained from the CTDEEP database. Data and analytical methods for collection of biogeochemical and physical data are available at www.lisicos.uconn.edu/ and www.lisicos.uconn.edu/ NutrientID.pdf. Biweekly to monthly data from 9 stations along LIS's primary axis were tabulated be- 
tween January 1995 and May 2009. The stations included A4, B3, C2, D3, E1, H4, I2, J2, and M3 (Fig. 1). Each survey included continuous depth profiles of density, temperature, salinity, and dissolved oxygen (DO). At each time point, $\delta \sigma, \delta \mathrm{T}$, and $\delta \mathrm{S}$ (bottom minus surface density, temperature, and salinity) were calculated as estimates of stratification conditions. Discrete Niskin bottle samples from 2 depths (surface and near-bottom) at each station were analyzed for concentrations of chl $a$, nitrate + nitrite $\left(\mathrm{NO}_{\mathrm{x}}\right)$, ammonium $\left(\mathrm{NH}_{4}{ }^{+}\right)$, orthophosphate (dissolved inorganic $\mathrm{P}, \mathrm{DIP})$, dissolved silicate (DSi), dissolved organic carbon (DOC), total dissolved $\mathrm{N}(\mathrm{TDN})$, total dissolved P (TDP), particulate $\mathrm{C}, \mathrm{N}, \mathrm{P}$ (PC, PN, PP), and biogenic $\mathrm{Si}(\mathrm{BioSi})$, and total suspended solids (TSS). C and $\mathrm{N}$ content measurements did not discriminate between organic or inorganic sources. DIN was calculated by summing $\mathrm{NH}_{4}{ }^{+}$and $\mathrm{NO}_{\mathrm{x}}$ for each sample. Dissolved organic fractions of $\mathrm{N}(\mathrm{DON})$ and $\mathrm{P}$ (DOP) were calculated by subtracting inorganic fractions from total dissolved pools. Atomic ratios of $\mathrm{C}: \mathrm{N}$ and $\mathrm{N}: \mathrm{P}$ were calculated for the particulate and dissolved inorganic fractions.

When examining nutrient stoichiometry, DIN:DIP ratios and $\mathrm{N}^{*}\left(\mathrm{~N}^{*}=\mathrm{N}-[16 \times \mathrm{P}]+2.90 \mu \mathrm{mol} \mathrm{kg}{ }^{-1}\right.$; Gruber \& Sarmiento 1997) were not employed because undetectable DIP concentrations would result in infinite DIN:DIP ratios, and stoichiometric corrections to $\mathrm{N}^{*}$ are not applicable to estuarine settings. Our solution was to use an excess DIN index (DINxs), where:

$$
\text { DINxs = DIN }-(16 \times \text { DIP })
$$

DINxs was originally developed to estimate relative contributions of $\mathrm{N}$ fixation and denitrification to

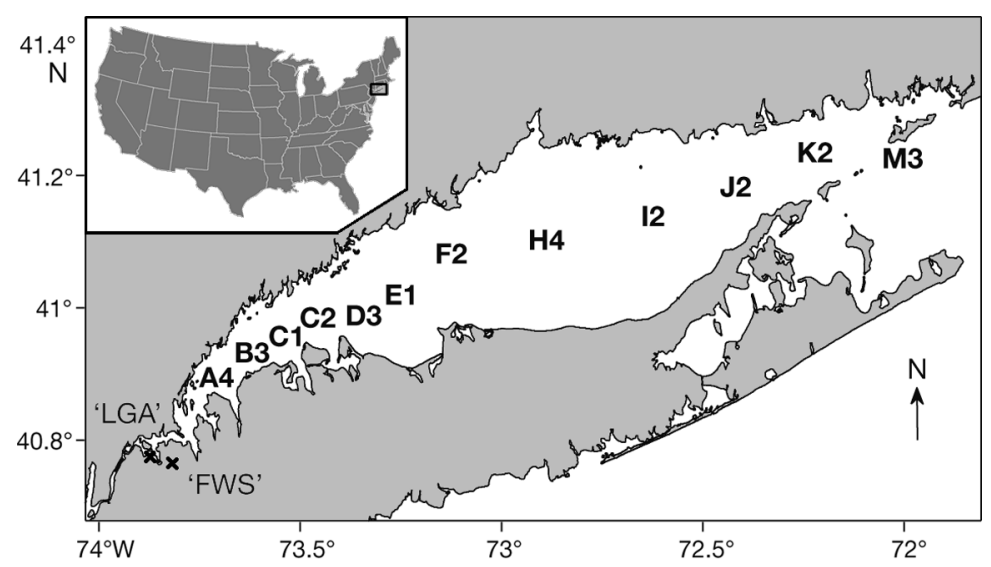

Fig. 1. Long Island Sound. A4 through M3 are stations at which nutrient and phytoplankton data were collected. La Guardia Airport (LGA) and Flushing (FWS) weather stations are meteorological data collection sites the $\mathrm{N}$ budget by estimating deviations from the Redfield ratio (16N:1P) (Hansell et al. 2004). For LIS, anthropogenic $\mathrm{N}$ loading and denitrification also affect the $\mathrm{N}$ budget, so the DINxs parameter is used solely as a 'Redfieldian' index of DIN relative to DIP concentrations, i.e. a DINxs of 0 equates to a DIN:DIP ratio of 16 , negative DINxs suggests N-limitation, and positive values suggest P-limitation.

\section{Phytoplankton community data}

In April 2002, CTDEEP augmented chl a measurements with detailed pigment analyses of samples taken from $2 \mathrm{~m}$ depth to monitor phytoplankton community composition. These analyses included biweekly to monthly sampling to May 2010 from Stns A4, B3, C1, D3, E1, F2, H4, I2, J2, and K2. Pigment concentrations were measured using high performance liquid chromatography (HPLC) by the Horn Point Analytical Services Laboratory (Cambridge, MD). Analyzed photopigments included chl $a$, divinyl-chl $a$, chl $b$, divinyl-chl $b$, chl $c 1 c 2, \operatorname{chl} c 3$, alloxanthin, antheraxanthin, $\beta$-carotene, canthaxanthin, diadinoxanthin, diatoxanthin, echinenone, butfucoxanthin, fucoxanthin, hex-fucoxanthin, gyroxanthin, and lutein. CTDEEP compared pigment concentrations to known assemblages from LIS using CHEMTAX and reported phytoplankton taxon abundance normalized to predicted chl a contribution (Li et al. 2004). Taxonomic groups include Bacillariophyceae (diatoms), Dinophyceae (dinoflagellates), cyanobacteria, Prasinophyceae, Chlorophyceae, Cryptophyceae, Prymnesiophyceae, Raphidophyceae, Eustigmatophyceae, Chrysophyceae, and Euglenophyceae. Diatoms frequently dominated total pigment inventories while nondiatom groups had smaller and variable contributions. Thus derived chl a contribution from the non-diatom ensemble was summed and considered as an additional statistical variable. The CHEMTAX method has previously been shown to underestimate the relative abundances of certain dinoflagellates and haptophytes due to unique pigment markers in some species of these groups (Irigoien et al. 2004). Furthermore, diatoms have a higher $\mathrm{chl}$ a:C ratio than other phytoplankton, and chl a estimates derived from the Chemtax method may overestimate their biomass (Llewellyn et al. 2005). We therefore took a conservative approach by only estimating 
interannual changes (as opposed to within-year seasonal evolution) using relative abundances in $\mathrm{chl} a$ units and did not attempt to estimate the overall contribution of taxa to total $\mathrm{C}$ biomass.

\section{Meteorological data}

Monthly precipitation totals from La Guardia Airport (Fig. 1) were acquired from the National Oceanic and Atmospheric Administration (NOAA, http://lwf.ncdc.noaa.gov/oa/ncdc.html). Monthly cloud cover $(\%)$ and wind speed at the Flushing weather station (Fig. 1) were acquired from Weather Underground (www.wunderground.com). Wind energy at the air-water interface was calculated as the square of the wind speed $\left(\mathrm{m}^{2} \mathrm{~s}^{-2}\right)$. Variability in monthly freshwater discharge into LIS was assessed exclusively using USGS tidal gauge data from the Connecticut (CT) River, because Hudson River discharge records from West Point, NY, were discontinuous (http://waterdata.usgs. gov/nwis). Moreover, the CT River contributes $>70 \%$ of riverine freshwater discharge into LIS, and thus represents a proxy for temporal variations and a conservative estimate of total freshwater input (Lee \& Lwiza 2005).

\section{Data processing}

To synchronize all measurements, data were linearly interpolated and resampled mid-month, at an evenly spaced gap of $30.5 \mathrm{~d}$, resulting in contemporaneous monthly data from each station and depth. To remove seasonality, the average annual cycle was calculated for each variable and station, then subtracted from respective monthly observations (e.g. Fig. 2). Seasonally-adjusted monthly anomalies were used for all statistics and comparisons.

Long-term trends of nutrients, total chl $a_{\text {, }}$ and the relative abundances of phytoplankton taxa in $\mathrm{chl} a$ units were analyzed using the Theil-Sen estimator (Wilcox 2005, Cloern et al. 2007). Associations between variables were estimated using the percentage bend correlation $\left(\mathrm{r}_{\mathrm{pb}}\right)$ (Wilcox 1994). These estimators are more robust than ordinary least squares methods and can be used on non-normal and heteroscedastic data (Wilcox 2005). Significance was determined by calculating $95 \%$ confidence intervals (CIs) from bootstrapping 599 estimates of either the Theil-Sen estimated trend or $\mathrm{r}_{\mathrm{pb}}$, as suggested by Wilcox (2005) for a dataset of this length $(\mathrm{n}=173)$, and using the middle $95 \%$ of these estimates. If the upper and lower

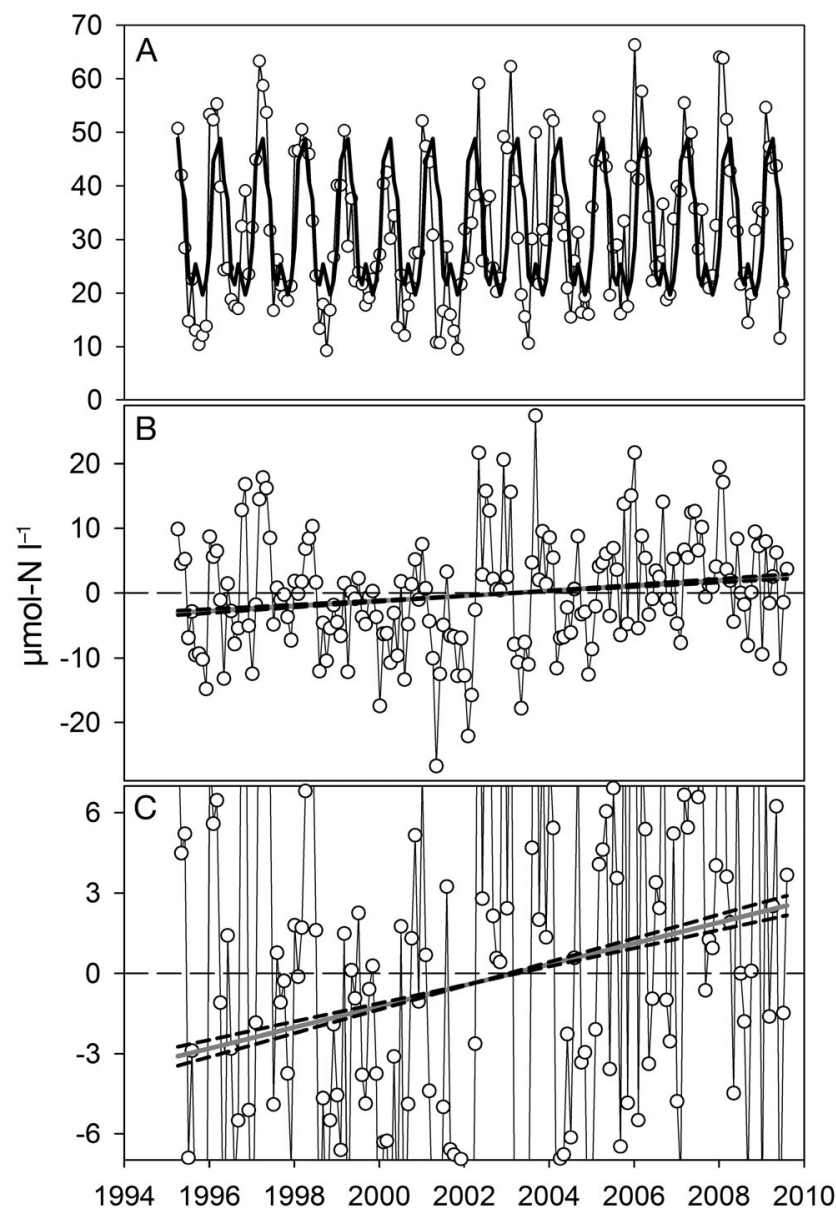

Fig. 2. Demonstration of calculation of the seasonallyadjusted anomalies and Theil-Sen trend. In (A), the monthly interpolated total dissolved $\mathrm{N}$ (TDN) concentrations are plotted as dots, and the bold black line is the average annual cycle. In (B), the anomalies are shown, which are the result of the average annual cycle from (A) subtracted from the monthly data from (A). In (C), the $y$-axis from (B) is expanded to show the trend calculated using the Theil-Sen

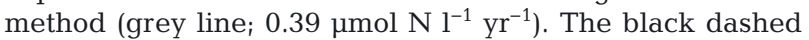
lines are the lower and upper limits (0.34 and $0.44 \mu \mathrm{mol} \mathrm{N} \mathrm{l^{-1 }}$ $\mathrm{yr}^{-1}$ ) of the $95 \%$ confidence interval of the trend after bootstrapping. The confidence interval does not straddle 0 , and therefore this trend is considered significant

limits were both positive (or both negative), the slope was considered significantly different than 0 , demonstrating a trend (Fig. 2B,C). Because of the distributions of some variables, CIs were not normally distributed about the trend ( $\mathrm{or}_{\mathrm{pb}}$ ), and therefore both upper and lower limits are presented.

To determine whether any variables underwent a significant shift to a new mean condition, changepoint analysis was performed (Pettitt 1980). Cumulative sums (CUSUM) of deviations from the mean were calculated according to the equation: 


$$
S_{i}=S_{i-1}+\left(X_{i}-\mu\right)
$$

where $S_{1}=0, X_{i}$ is the original time series anomaly value, and $\mu$ is the mean of the variable being considered. In addition, $S_{\text {diff }}$ (maximum $S$ - minimum $S$ ) was calculated for each variable. $S$ was then plotted against time. Points at which $S$ changed from increasing to decreasing or decreasing to increasing were considered as possible change-points. Significance of each change-point was determined by bootstrapping 1000 random reorderings of the original data and calculating $S$ and $S_{\text {diff }}$ for each reordering. If $>95 \%$ of the reordered $S_{\text {diff }}$ values were less than the actual $S_{\text {diff }}$ value, the change-point was considered significant.

Once a change-point in chl a was determined, canonical correlation analysis (CCA) was used to determine how phytoplankton biomass covaried with other variables in time. This multivariate approach was chosen because it takes into account multiple predictor $(x)$ and predictand $(y)$ variables at once, and extracts a pattern of interannual covariation, making the method superior to linear and multiple linear regressions and robust for ecological applications (Wilks 2006). CCA calculates a linear combination from each of 2 datasets (called canonical variables, or modes) such that the correlation between the 2 modes is maximized. It proceeds by removing the variability of the first modes to find the subsequent 2 modes with the next highest correlation coefficient until the number of pairs of modes equals the number of variables in the smaller of the 2 original datasets (Barnett \& Preisendorfer 1987). All variables were standardized by subtracting the mean and dividing by the standard deviation, then concatenated into matrices according to variable type: planktonic biomass indices (chl a, TSS, PC, PN, PP, BioSi), nutrients $\left(\mathrm{NH}_{4}{ }^{+}, \mathrm{NO}_{\mathrm{x}}, \mathrm{DIN}, \mathrm{TDN}, \mathrm{DIP}, \mathrm{TDP}\right.$, DSi, DOC, DON, DOP), hydrographic/meteorological variables (temperature, salinity, density, $\delta \mathrm{T}, \delta \mathrm{S}$, $\delta \sigma, \mathrm{DO}$, cloud cover, wind energy, precipitation, and CT River discharge) and phytoplankton taxa from HPLC pigment analysis (similar to Levine \& Schindler 1999). Datasets were pre-filtered using principal component analysis (PCA), and the leading orthogonal components of each matrix explaining $>80 \%$ of the variance were retained as input for CCA (Moron et al. 2006). Resulting canonical components were then compared to original data using a heterogeneous correlation (Levine \& Schindler 1999, Wilks 2006), which correlates the predictors with the modes from the predictands and the predictands with the modes from the predictors in order to determine which of the original variables were most associated with the interannual patterns extracted by CCA. Percentage-bend correlation, change-point analyses, and CCA were only performed with data from Stn A4 because this station exhibited the largest changes in nutrient concentrations and phytoplankton biomass. Furthermore, A4 is the westernmost station in this analysis and is consequently the most influenced by sewage-derived nutrients from NYC WWTPs and by seasonal hypoxia (Sweeney \& Sañudo-Wilhelmy 2004).

\section{RESULTS}

\section{Fifteen-year analysis of nutrients}

Total annual N loads from all WWTPs discharging into LIS declined from $36.8 \times 10^{3}$ in 1994 to $24.7 \times$ $10^{3}$ standard tons $\mathrm{N}$ in 2010 (Fig. 3, grey bars). The majority of this decline occurred between 1994 and 2002. Between 2002 and 2010, annual WWTPsourced $\mathrm{N}$ loads remained relatively constant, varying between $24.7 \times 10^{3}$ and $29.6 \times 10^{3}$ tons $\mathrm{N}$. Data on P loadings from NYC WWTPs are available starting in 2005 (Fig. 3, green line). For comparison, total N loads from only NYC WWTPs are also presented for 2005 to 2010 (Fig. 3, red line). From 2005 to 2010, total annual $\mathrm{N}$ and $\mathrm{P}$ loadings from NYC showed no major changes.

Interannual trends in some deseasonalized variables displayed reversals in the year 2000 (also discussed by LISS: http://longislandsoundstudy.net/ 2010/07/chlorophyll-a-abundance/). However, trends prior to and after this reversal were unidirectional.

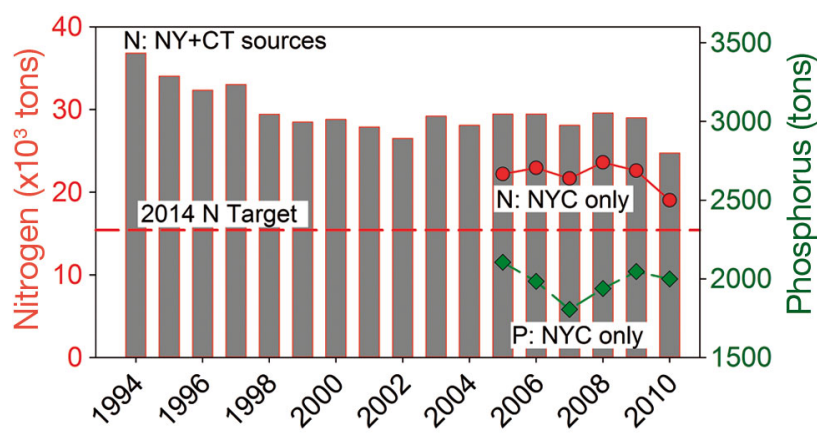

Fig. 3. Total annual $\mathrm{N}$ loads (standard tons, grey bars) from all waste water treatment plants (WWTPs) from New York (NY) and Connecticut (CT) discharging into Long Island Sound (LIS). Red dashed line is the 2014 goal of $58.75 \%$ of the total maximum daily loads. Annual $\mathrm{N}$ loads from the 4 WWTPs discharging into western LIS from New York City (NYC) are shown with red circles, and annual P loads from the 4 plants are shown with green diamonds 
Therefore rates of change in this section reflect the entire observation period, while the shift that occurred in 2000 is discussed below under 'Changepoint analysis.' Fifteen-year interannual rates of change in selected variables are presented in Figs. 4-9. TDN concentrations increased at most stations in both surface and bottom waters, especially in western LIS, as a result of increased DON stocks (Fig. 4A,B). DIN concentrations decreased at all stations except at A4 (Fig. 4A-C). The modest decreases in DIN at most stations were driven by decreases in concentrations of $\mathrm{NO}_{\mathrm{x}}$ (Fig. 4D). There were no consistent trends in $\mathrm{NH}_{4}{ }^{+}$concentrations, except at Stn A4, where they significantly increased (Fig. 4E). Unlike N, dissolved P and Si stocks increased between 1995 and 2009. TDP concentrations increased at all central and western stations, with DIP stocks driving 82 to $100 \%$ of those increases (Fig. 5). DSi concentrations increased at all stations in surface and bottom waters (Fig. 6A) while particulate BioSi decreased (Fig. 6B). Increases in DSi were generally larger than decreases in $\mathrm{BioSi}$, and so total Si significantly increased at most stations (Fig. 6C).

$\mathrm{Chl} a$ increased significantly in surface and bottom waters between 1995 and 2009, with trends varying from 0.09 to $0.56 \mu \mathrm{g} \mathrm{chl} \mathrm{l}^{-1} \mathrm{yr}^{-1}$ among the 9 stations (Fig. 7A). In contrast, TSS decreased at most stations but with no consistent spatial pattern (Fig. 7B). PC and PN concentrations, which include both living and detrital $\mathrm{C}$ and $\mathrm{N}$, significantly decreased at most stations, with the most pronounced decreases in the west (Figs. $7 \mathrm{C}, \mathrm{D}$ ). Measurable changes in PP were not apparent (not shown). Differential rates of change among $\mathrm{PC}, \mathrm{PN}$, and $\mathrm{PP}$ caused increases in $\mathrm{PC}: \mathrm{PN}$ ratios $\left(3-15 \% \mathrm{yr}^{-1}\right)$ and decreases in PN:PP ratios (17-50\% $\mathrm{yr}^{-1}$ among all stations). Interannual changes in the PN:BioSi ratio were not evident at any station (not shown), because both $\mathrm{PN}$ and BioSi declined at similar rates. Collectively, variations in particulate nutrient ratios indicate that the planktonic community has become increasingly depleted in $\mathrm{N}$ and $\mathrm{Si}$ relative to $\mathrm{C}$ and $\mathrm{P}$.

Nutrient stoichiometry necessarily changed as a consequence of varying interannual trends among nutrients. The DINxs index significantly decreased in surface and bottom waters, with the largest changes in the west (Fig. 8). Dissolved nutrients remained near the Redfield ratio only at the eastern-most station, while DIN depletion accelerated in a westerly direction. Overall, changes in the DINxs parameter were driven by differential changes in total DIN and DIP pools. DIN stocks declined from an average of $10.1 \pm 0.6(\mathrm{SE}) \mu \mathrm{mol} \mathrm{l^{-1 }}$ among all stations in the first

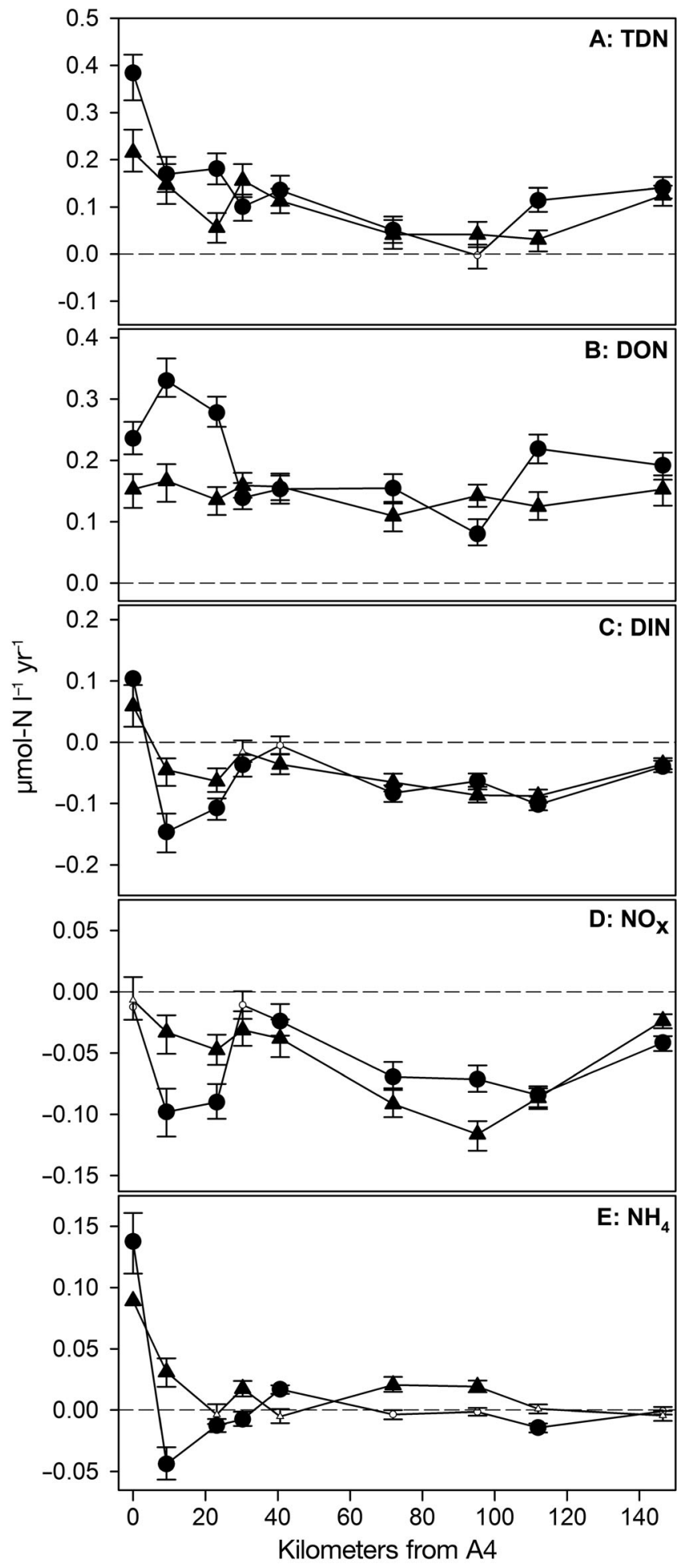

Fig. 4. Annual rates of change in concentrations of (A) total dissolved nitrogen (TDN), (B) dissolved organic nitrogen (DON), (C) dissolved inorganic nitrogen (DIN), (D) nitrate + nitrite $\left(\mathrm{NO}_{\mathrm{x}}\right)$, and (E) $\mathrm{NH}_{4}{ }^{+}$in surface and bottom waters at the 9 stations analyzed. (@) surface samples; ( $\mathbf{\Delta})$ bottom samples. (O) trends that are not significant at the $95 \%$ level, i.e. the confidence interval (CI) straddles 0 . The $x$-axis shows distance from Stn A4. Error bars represent the $95 \%$ CI 


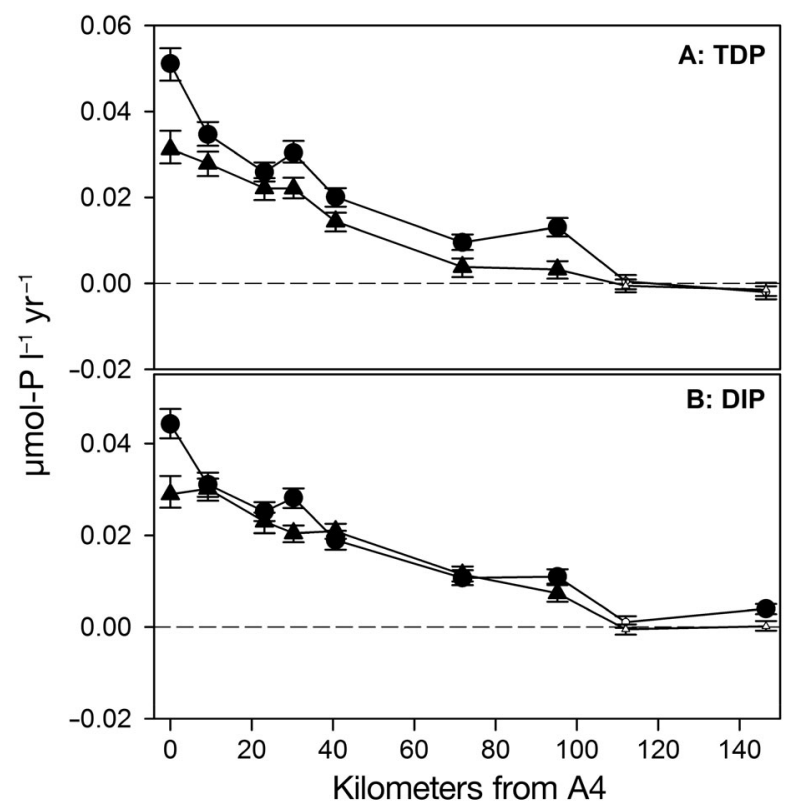

Fig. 5. Annual rates of change in concentrations of (A) total dissolved phosphorus (TDP) and (B) dissolved inorganic phosphorus (DIP) in surface and bottom waters at the 9 stations analyzed. Symbols and format are same as for Fig. 4

year of analysis, to an average of $6.7 \pm 0.4 \mu \mathrm{mol} \mathrm{l}^{-1}$ in the last 12 mo of analysis, while DIP stocks increased from $1.1 \pm 0.02$ to $1.2 \pm 0.03 \mu \mathrm{mol} \mathrm{l}^{-1}$.

Trends in hydrographic and meteorological parameters were analyzed to determine possible drivers for observed changes. However, relative to the nutrient and phytoplankton biomass parameters, most hydrographic parameters displayed little to no change over the $15 \mathrm{yr}$ observation period (Table 1). Overall, $\delta \sigma$ indicated small but significant decreases in stratification at Stn A4 and increases at stations in the central and eastern basins. Small, significant decreases in bottom water DO concentrations were also observed at the 3 westernmost stations and 1 easternmost station, while no significant changes were observed for central stations.

\section{Eight-year phytoplankton community analyses}

Of the major phytoplankton groups, diatoms exhibited the most pronounced long-term change, with consistent declines at all western and central stations. Diatom-chl a decreased by $41 \%$ at Stn A4, while the chl a contribution from all other groups increased (Fig. 9). The increase in chl a contributions from the non-diatom ensemble was driven by growing inventories of dinoflagellates, Prymnesiophyceae, Cryptophyceae, Raphidophyceae, and Eug-

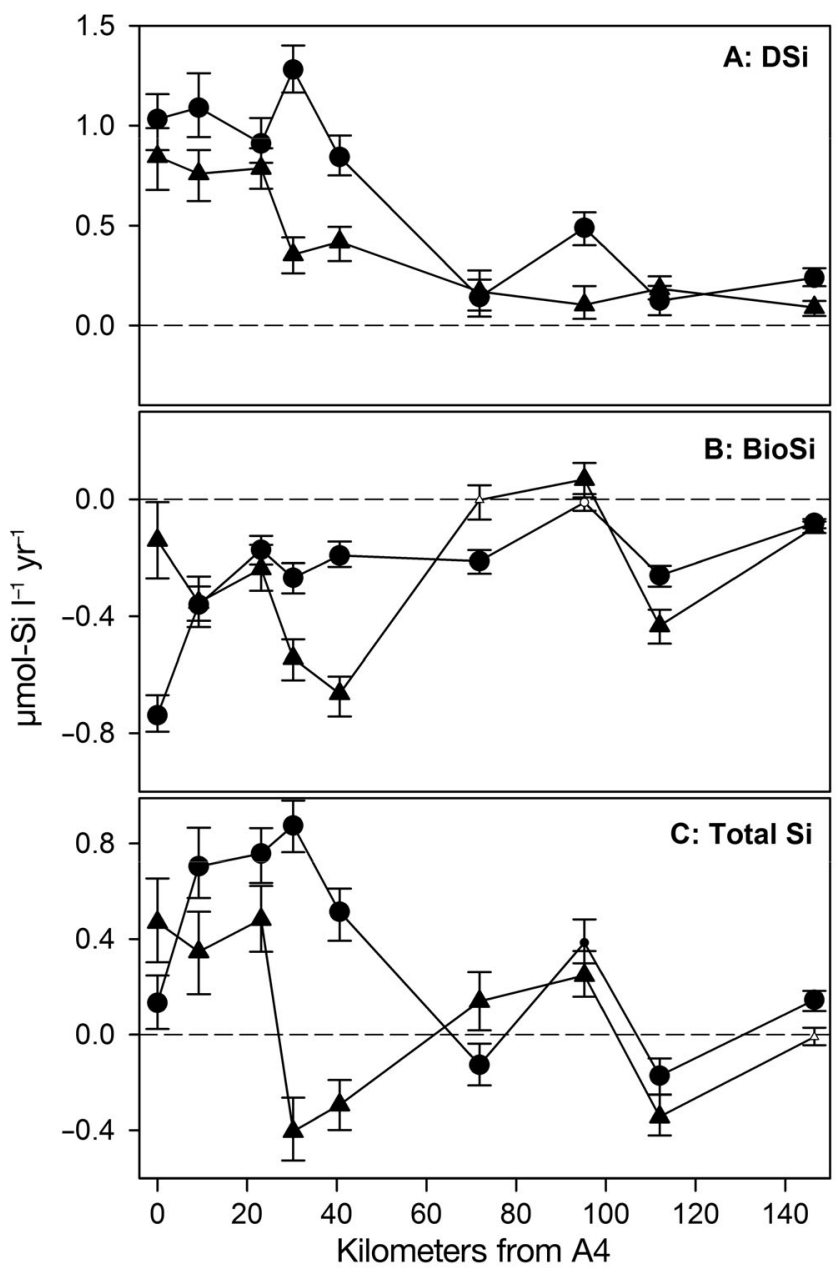

Fig. 6. Annual rates of change in concentrations of (A) dissolved silicate (DSi), (B) biogenic silica (BioSi), and (C) total silica in surface and bottom waters at the 9 stations analyzed. Symbols and format are same as for Fig. 4

lenophyceae (not shown). For all other groups, changes were small to undetectable. As a portion of total chl $a$, diatom abundances decreased from $62.3 \pm$ $2.0 \%$ in the first 12 mo of analysis to $52.5 \pm 2.2 \%$ in the last 12 mo of analysis, among all stations. Therefore, despite large declines, diatoms remained the most abundant phytoplankton taxa on average throughout the entire period of analysis. However, the frequency of events in which diatoms were the dominant taxa declined. In the first 12 mo of analysis, diatoms were $<10 \%$ of the total community on 3 occasions among all samples from all stations. In the last $12 \mathrm{mo}$, diatoms were $<10 \%$ of the community on 11 occasions.

Using $\mathrm{r}_{\mathrm{pb}}$ analysis, anomalies in chl a contributions of phytoplankton taxa at Stn A4 were compared to anomalies in other variables between 2002 and 2009 (Table 2). Total chl $a$, TSS, and BioSi anomalies were 


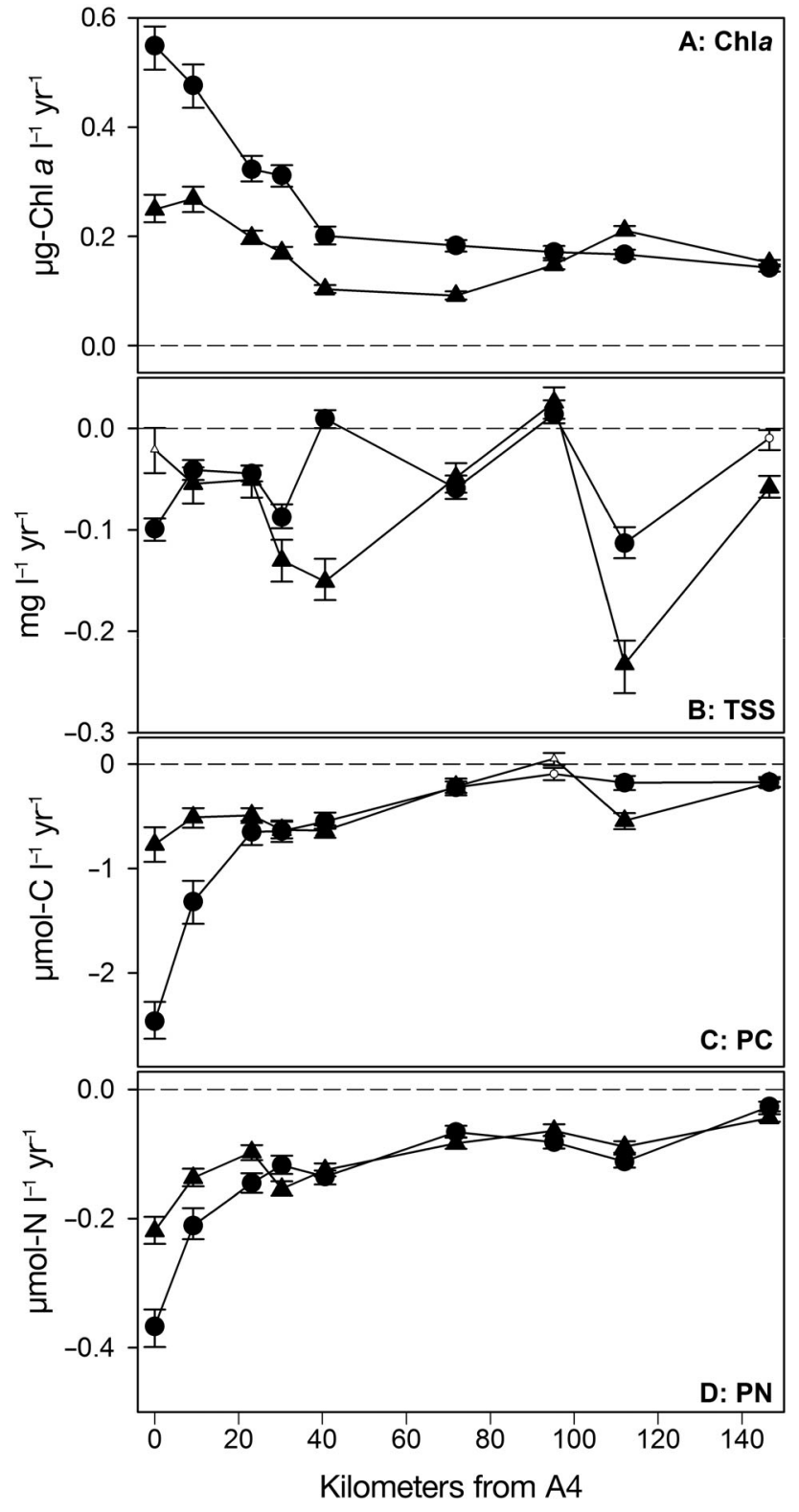

Fig. 7. Annual rates of change in concentrations of (A) chl $a$, (B) total suspended solids (TSS), (C) particulate carbon (PC), and (D) particulate nitrogen (PN) in surface and bottom waters at the 9 stations analyzed. Symbols and format are same as for Fig. 4

positively correlated with those for diatom-chl $a$. Therefore, despite decreasing contributions of diatom-chl a during this period, diatoms remained more closely correlated with chl a than any other single phytoplankton taxon. This also supports the use of BioSi as a proxy for trends in diatoms pre-2002 (when HPLC data were not available). In addition, Cryptophyceae and Raphidophyceae were negatively correlated with total chl $a_{\text {, }}$ and BioSi and Prymnesiophyceae were positively related to TSS, suggesting

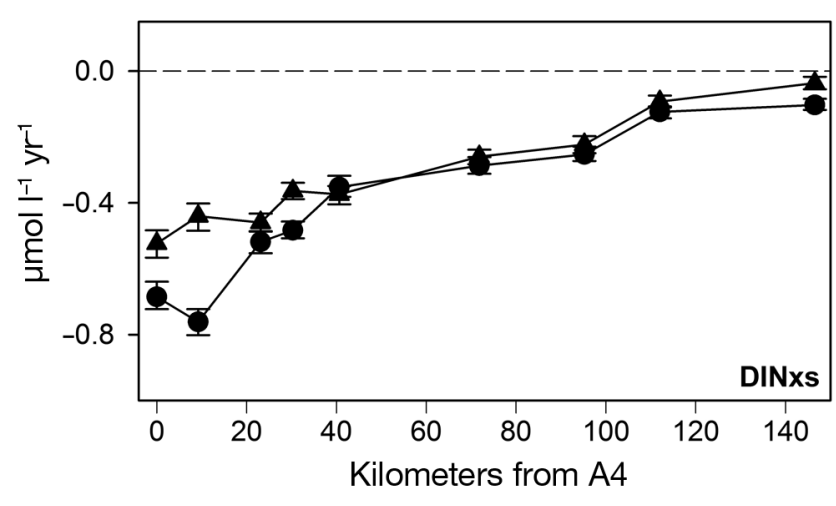

Fig. 8. Annual rates of change in the excess dissolved inorganic nitrogen index (DINxs) parameter in surface and bottom waters at the 9 stations analyzed. Symbols and format are same as for Fig. 4

that this group contributes to variability in total suspended biomass, but not consistently to total chl a.

Correlation analyses also showed that diatom abundances in Stn A4 surface waters were strongly associated with concentrations of all inorganic nutrients and DINxs. Interannual variations in diatom abundance anomalies were also strongly related with those of $\mathrm{PC}$, $\mathrm{PN}$, and $\mathrm{PP}$, suggesting that diatoms can explain much of the variability in total particulate pools. Total chl a apportioned to the non-diatom ensemble showed no relationships with any nutrients (Table 2). However, Prasinophyceae concentrations were positively correlated with TDN, and Cryptophyceae covaried with most inorganic $\mathrm{N}$ and $\mathrm{P}$ pools. Furthermore, DON anomalies were positively correlated with anomalies in the individual Prasinophyceae and Cryptophyceae groups. PC and PN anomalies were weakly correlated with chl a contributed by the nondiatom ensemble. Together, these results suggest that diatoms are limited by inorganic $\mathrm{N}$ and $\mathrm{P}$, and control the variability in most planktonic particulate pools, while the non-diatom ensemble is not as sensitive to inorganic nutrient dynamics and only covaries slightly with some particulate pools.

Diatom-chl $a$ at Stn A4 surprisingly also covaried with salinity stratification $(\delta \mathrm{S})$. To determine whether this result was unique to Stn A4, we also performed $\mathrm{r}_{\mathrm{pb}}$ analyses at Stn J2 in the eastern basin of LIS, which has a more offshore character. At J2, diatomchl a was negatively correlated with $\delta \mathrm{T}$, indicating a negative relationship with thermal stratification $\left(\mathrm{r}_{\mathrm{pb}}=\right.$ -0.23 ; CI $=-0.39$ to -0.02 ). This relationship confirmed that in eastern LIS, as observed elsewhere, diatoms tend to respond negatively to stratification and are displaced by mixed assemblages of flagellated taxa. The unexpected dynamic between diatoms and stratification at Stn A4 is discussed later. 


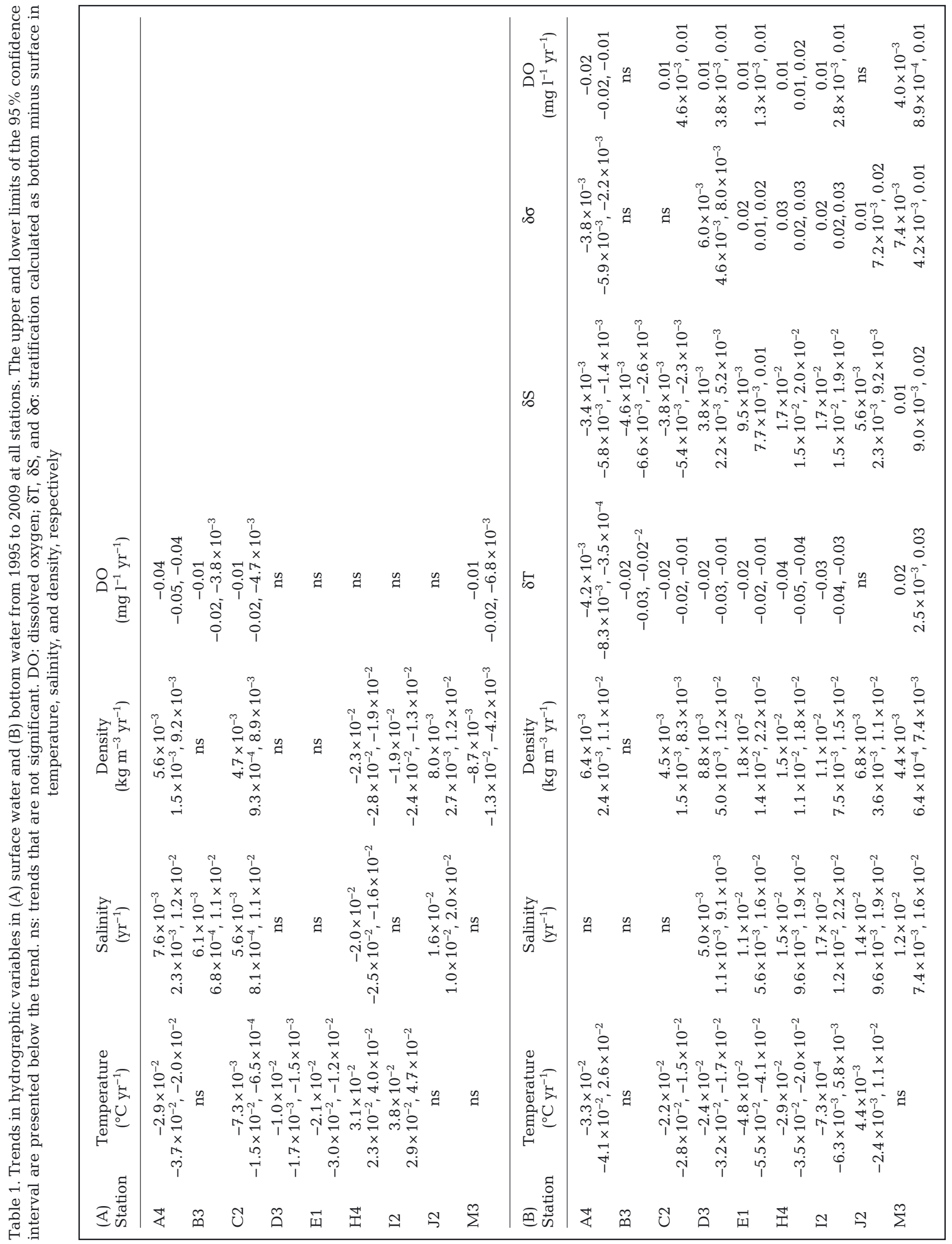




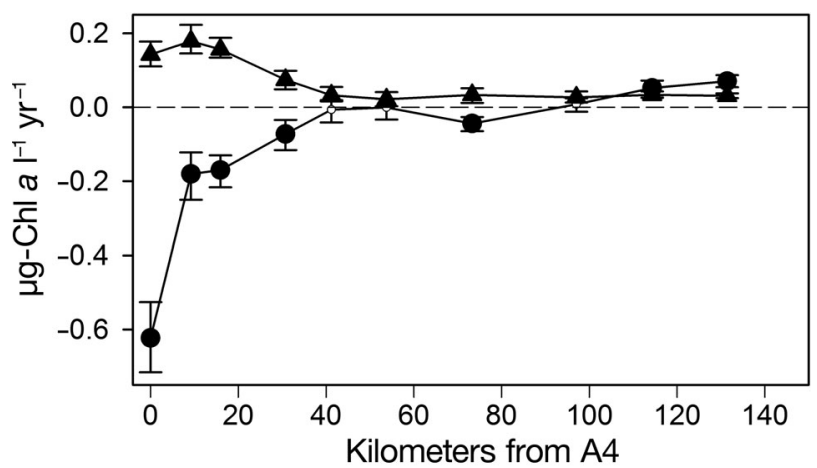

Fig. 9. Annual rates of change in chl a from diatoms (O) and from all other phytoplankton groups $(\mathbf{\Delta})$. (O) trends that are not significant at the $95 \%$ level. The $x$-axis shows distance from Stn A4. Error bars represent the $95 \%$ CI
Lastly, variations in diatom populations as well as all other phytoplankton taxa did not relate to those in bottom water DO concentrations. However, bottom water DO concentrations did positively correlate with total chl a $\left(\mathrm{r}_{\mathrm{pb}}=0.31 ; \mathrm{CI}=0.16,0.47\right)$, TDP $\left(\mathrm{r}_{\mathrm{pb}}=\right.$ -0.22 ; $\mathrm{CI}=-0.37,-0.09)$, DIP $\left(\mathrm{r}_{\mathrm{pb}}=-0.24 ; \mathrm{CI}=-0.42\right.$, $-0.08)$, and temperature $\left(\mathrm{r}_{\mathrm{pb}}=-0.31 ; \mathrm{CI}=-0.43\right.$, -0.16). Surprisingly, bottom water DO did not correlate with any measure of stratification.

Comparisons between phytoplankton taxa chl a contribution and planktonic biomass indices using CCA resulted in 2 modes that were significantly correlated: modes $1(\mathrm{r}=0.84 ; \mathrm{p}<0.0001)$ and $2(\mathrm{r}=0.44$; $\mathrm{p}<0.0001)$. The first mode showed correlations similar to those found by $\mathrm{r}_{\mathrm{pb}}$ analysis, further validating

Table 2. Percentage bend correlation coefficients $\left(\mathrm{r}_{\mathrm{pb}}\right)$ between chl a contribution from relevant phytoplankton taxa, and selected biological, nutrient, and hydrographic data between 2002 and 2009. The upper and lower limits of the $95 \%$ confidence interval of the $r_{p b}$ are presented below the coefficient. ns: correlations that are not significant. Groups of phytoplankton pigments or field data that did not correlate with any other variables are omitted. Values of phytoplankton pigments are in $\mu \mathrm{g}^{-1}$. All other values are in $\mu \mathrm{mol}^{-1}$ unless shown otherwise. TSS: total suspended solids; TDN (TDP): total dissolved nitrogen (phosphorus); DIN (DIP): dissolved inorganic nitrogen (phosphorus); DSi: dissolved silicate; PC: particulate carbon; PN: particulate nitrogen; PP: particulate phosphorus; DON: dissolved organic nitrogen; $\delta$ S: change in salinity

\begin{tabular}{|c|c|c|c|c|c|c|}
\hline & Diatoms & $\begin{array}{l}\text { Prasino- } \\
\text { phyceae }\end{array}$ & $\begin{array}{l}\text { Crypto- } \\
\text { phyceae }\end{array}$ & $\begin{array}{c}\text { Prymnesio- } \\
\text { phyceae A }\end{array}$ & $\begin{array}{l}\text { Raphido- } \\
\text { phyceae }\end{array}$ & $\begin{array}{l}\text { All non-diatom } \\
\text { ensembles }\end{array}$ \\
\hline $\mathrm{Chl} \mathrm{a}\left(\mu \mathrm{gl}^{-1}\right)$ & $\begin{array}{c}0.72 \\
0.53,0.82\end{array}$ & ns & $\begin{array}{c}-0.25 \\
-0.45,-0.09\end{array}$ & ns & $\begin{array}{c}-0.20 \\
-0.44,-7.1 \times 10^{-4}\end{array}$ & ns \\
\hline $\operatorname{TSS}\left(\mathrm{mg} \mathrm{l}^{-1}\right)$ & $\begin{array}{c}0.34 \\
0.09,0.51\end{array}$ & ns & ns & $\begin{array}{c}0.33 \\
0.07,0.53\end{array}$ & $\mathrm{~ns}$ & ns \\
\hline TDN & $\begin{array}{c}-0.41 \\
-0.56,-0.23\end{array}$ & $\begin{array}{c}0.21 \\
0.02,0.42\end{array}$ & $\begin{array}{c}0.32 \\
0.12,0.52\end{array}$ & ns & ns & ns \\
\hline TDP & $\begin{array}{c}-0.42 \\
-0.60,-0.18\end{array}$ & ns & $\begin{array}{c}0.26 \\
0.06,0.46\end{array}$ & ns & ns & ns \\
\hline $\mathrm{NH}_{4}^{+}$ & $\begin{array}{c}-0.45 \\
-0.60,-0.27\end{array}$ & ns & $\begin{array}{c}0.28 \\
0.09,0.46\end{array}$ & $\begin{array}{c}-0.22 \\
-0.42,-1.2 \times 10^{-3}\end{array}$ & ns & ns \\
\hline $\mathrm{NO}_{\times}$ & $\begin{array}{c}-0.24 \\
-0.41,-0.04\end{array}$ & ns & ns & ns & ns & ns \\
\hline DIN & $\begin{array}{c}-0.37 \\
-0.56,-0.19\end{array}$ & ns & $\begin{array}{c}0.30 \\
0.09,0.49\end{array}$ & ns & ns & ns \\
\hline DIP & $\begin{array}{c}-0.44 \\
-0.60,-0.21\end{array}$ & ns & $\begin{array}{c}0.23 \\
0.05,0.44\end{array}$ & ns & ns & ns \\
\hline DSi & $\begin{array}{c}-0.42 \\
-0.57,-0.25\end{array}$ & ns & ns & ns & ns & ns \\
\hline $\mathrm{PC}$ & $\begin{array}{c}0.71 \\
0.53,0.83\end{array}$ & ns & ns & $\begin{array}{c}0.30 \\
0.05,0.52\end{array}$ & ns & $\begin{array}{c}0.24 \\
0.02,0.45\end{array}$ \\
\hline $\mathrm{PN}$ & $\begin{array}{c}0.65 \\
0.44,0.79\end{array}$ & ns & ns & $\begin{array}{c}0.30 \\
0.07,0.50\end{array}$ & ns & $\begin{array}{l}0.21 \\
4.5 \times 10^{-3}, 0.43\end{array}$ \\
\hline PP & $\begin{array}{c}0.58 \\
0.38,0.74\end{array}$ & $\begin{array}{c}0.24 \\
0.09,0.43\end{array}$ & ns & ns & ns & ns \\
\hline Biogenic silica & $\begin{array}{c}0.60 \\
0.46,0.73\end{array}$ & ns & $\begin{array}{c}-0.26 \\
-0.43,-0.06\end{array}$ & ns & $\begin{array}{c}-0.25 \\
-0.43,-0.05\end{array}$ & ns \\
\hline DON & ns & $\begin{array}{c}0.35 \\
0.16,0.56\end{array}$ & $\begin{array}{c}0.30 \\
0.07,0.50\end{array}$ & ns & ns & ns \\
\hline DINxs & $\begin{array}{c}0.35 \\
0.07,0.49\end{array}$ & ns & ns & ns & ns & ns \\
\hline$\delta \mathrm{S}$ & $\begin{array}{c}0.26 \\
0.10,0.41\end{array}$ & ns & ns & ns & ns & ns \\
\hline
\end{tabular}


those results (not shown). In addition, heterogeneous correlation of the second mode from CCA revealed some new relationships that were not apparent with univariate statistics: dinoflagellates $(\mathrm{r}=0.44, \mathrm{p}<$ $0.0001)$, Prasinophyceae $(r=0.28, \mathrm{p}=0.008)$, and PP $(\mathrm{r}=0.40, \mathrm{p}=0.0001)$ covaried on interannual timescales. Therefore, while diatoms strongly controlled the variability in total chl $a$, suspended particulate $C$, N, P, and Si biomass, dinoflagellates and Prasinophyceae were also tied to the variability of PP biomass. Comparison of planktonic biomass indices to hydrographic/meteorological variables using CCA also only revealed similar relationships to what was shown by the $\mathrm{r}_{\mathrm{pb}}$ analysis (not shown).

\section{Change-point analysis}

Paradoxically, the above results suggest that while diatoms covaried with total $\mathrm{chl} a$, and all other indices of particulate biomass on a monthly basis between 2002 and 2009, total chl a increased as particulate concentrations decreased over 15 yr. CUSUM charts showed that average chl a concentrations changed significantly within the time series; inventories were below average before July 2000, and above average after July 2000 (Fig. 10). Furthermore, chl a stocks were significantly declining before $\left(-1.6 \mu \mathrm{g}^{-1} \mathrm{yr}^{-1}\right.$; $\mathrm{CI}=-1.8,-1.4)$ and after $\left(-0.46 \mu \mathrm{g}^{-1} \mathrm{yr}^{-1} ; \mathrm{CI}=-0.5\right.$, -0.3) this change-point, but statistically significant increases over the entire time series were due to the one dramatic increase in average concentrations in the year 2000. To determine a possible cause for this shift at Stn A4, CCA was used to identify interannual patterns of covariance between the planktonic biomass indices and other variables over the $15 \mathrm{yr}$ period. The first mode in the comparison between planktonic biomass indices and nutrients $(\mathrm{r}=0.54$, $\mathrm{p}<0.001)$ significantly decreased throughout the record (Fig. 11). A heterogeneous correlation revealed that this mode was correlated with all of the planktonic biomass indicators (PC, PN, PP, BioSi, chl $a$, and TSS) and with inorganic nutrients (TDN, TDP, $\mathrm{NH}_{4}{ }^{+}$, $\mathrm{NO}_{\mathrm{x}}, \mathrm{DIN}, \mathrm{DIP}$, and DSi; for coefficients see figure legend). These results were similar to that of the $r_{p b}$ analysis. However, CCA also revealed that this pattern of association between planktonic biomass indicators and inorganic nutrients exhibited a steady, significant decline between 1995 and 2009 without a dramatic shift in mean concentrations in 2000. Furthermore, the planktonic biomass indicators were previously shown to positively covary strongly with diatom-chl $a$, and more weakly with Prymnesio-

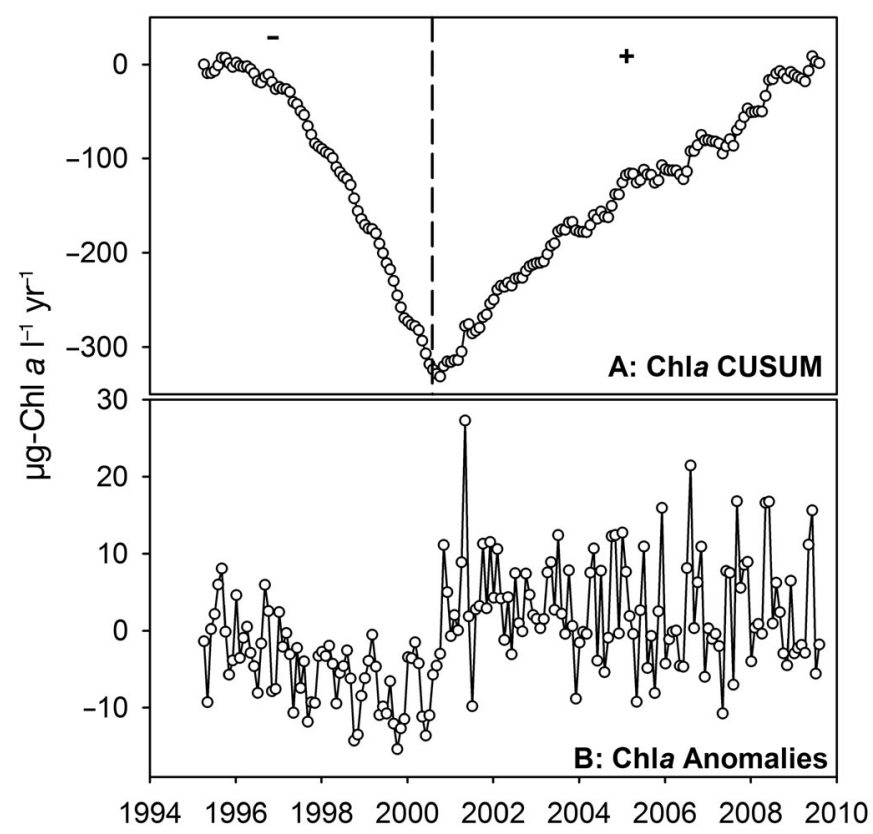

Fig. 10. (A) Cumulative sums (CUSUM) chart of anomalies of surface chl $a$ at Stn A4. Dashed lines shows the changepoints (July 2000: maximum $S$ - minimum $S$ [= $S_{\text {diff; }}$ see 'Materials and methods'] $=340.0$, significant at the $95 \%$ level). Positive and negative signs indicate which regions of the time series were above (+) or below (-) average. (B) For reference, the original chl $a$ anomaly time series at $\mathrm{A} 4$ is shown

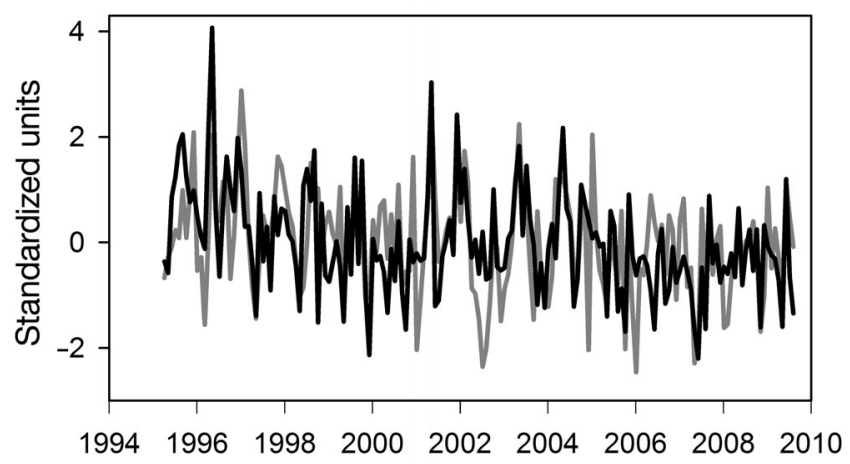

Fig. 11. Time series expansion of the results of the canonical correlation analysis between nutrient variables (grey line) and phytoplankton biomass indices (black line) for the first canonical variate between 1995 and 2009. The first mode of nutrient variables was highly correlated with PC ( $\mathrm{r}=-0.53$, $\mathrm{p}<0.0001$; abbreviations as in Table 2), PN ( $\mathrm{r}=-0.52, \mathrm{p}<$ 0.0001), PP ( $\mathrm{r}=-0.38, \mathrm{p}<0.0001)$, BioSi $(\mathrm{r}=-0.34, \mathrm{p}<$ $0.0001)$, chl $a(r=-0.21, \mathrm{p}=0.006)$ and TSS $(\mathrm{r}=-0.24, \mathrm{p}=$ $0.003)$. The first mode of interannual pattern in planktonic biomass indices was highly correlated with TDN ( $\mathrm{r}=0.40$, $\mathrm{p}<0.0001)$, TDP $(\mathrm{r}=0.45, \mathrm{p}<0.0001), \mathrm{NH}_{4}{ }^{+}(\mathrm{r}=0.40, \mathrm{p}<$ $0.0001), \mathrm{NO}_{\mathrm{x}}(\mathrm{r}=0.29, \mathrm{p}<0.0001) \mathrm{DIN}(\mathrm{r}=0.42, \mathrm{p}<0.0001)$, DIP $(\mathrm{r}=0.44, \mathrm{p}<0.0001)$, and DSi $(\mathrm{r}=0.42, \mathrm{p}<0.0001)$. These first modes significantly decreased $\left(-1.4 \times 10^{-4}, \mathrm{CI}=\right.$ $-1.6 \times 10^{-4},-1.3 \times 10^{-4}$ for the nutrient variables and $-2.1 \times$ $10^{-4}, \mathrm{CI}=-2.3 \times 10^{-4},-2.0 \times 10^{-4}$ for the planktonic biomass variables). Units are standardized 


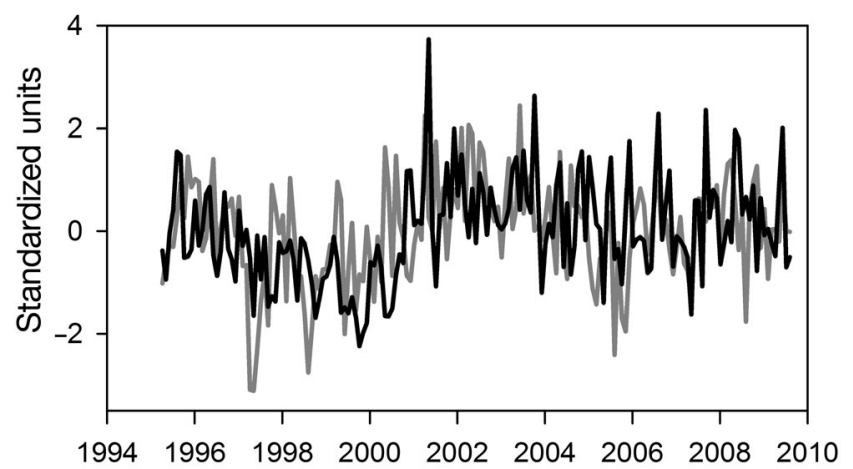

Fig. 12. Time series expansion of the results of the canonical correlation analysis between hydrographic/meteorological variables (grey line) and phytoplankton biomass indices (black line) for the first mode between 1995 and 2009. The first mode in hydrographic/meteorological variables was correlated with chl a $(\mathrm{r}=0.26, \mathrm{p}=0.0005)$, particulate phosphorus $(\mathrm{r}=0.28, \mathrm{p}=0.0005)$, and more weakly with biogenic silica $(r=0.16, p=0.03)$. The first mode in planktonic biomass indices was correlated with surface temperature $(\mathrm{r}=$ $-0.20, p=0.01)$, salinity $(r=0.15, p=0.05)$, and density $(r=$ $0.19, p=0.01)$

phyceae and Prasinophyceae (Table 2), suggesting that these groups underwent the long-term declines observed in this mode.

Comparisons between planktonic biomass indices and hydrographic/meteorological variables revealed a high coherence for the first mode $(r=0.38, \mathrm{p}<$ 0.0001 ), which did reproduce the reversals in phytoplankton biomass in 2000 (Fig. 12). Heterogeneous correlation analysis revealed that this interannual pattern was positively correlated with chl $a$, PP, and $\mathrm{BioSi}$, negatively with temperature, and positively with salinity and density. None of the other hydrographic/meteorological variables were in this mode, including bottom water DO and stratification, suggesting that contemporaneous changes in surface and bottom water temperature and salinity were important to this relationship. Together, CCA revealed that the shift in chl $a$ at Stn A4 that occurred in July 2000 was associated with increases in P-rich biomass (previously shown to covary with dinoflagellates, Prasinophyceae, and diatoms), BioSi (shown to covary with diatoms), and changing temperature and salinity conditions.

\section{DISCUSSION}

\section{Trends in LIS over $15 \mathrm{yr}$}

This study revealed several major changes in biomass, nutrient concentrations, and stoichiometry oc- curring over the last 15 yr in LIS. While a study of this scale can inflate Type I error (false positives), most trends were observed at all stations or displayed a clear spatial gradient, suggesting that trends were real and significant. For example, Sound-wide increases in DON despite decreases in inorganic $\mathrm{N}$ concentrations caused total $\mathrm{N}$ stocks to increase, particularly in the western and central Sound. While declines in DIN were likely driven by decreased anthropogenic loadings, the mechanism for escalating DON concentrations is less clear. DON concentrations are typically elevated in urban receiving waters because secondary treatment of sewage does not completely eliminate dissolved organics from effluent (Bronk et al. 2010). While these organics have long been thought to be refractory, some recent studies have shown that the bioavailability of 'effluent organic $\mathrm{N}^{\prime}$ can change once it enters an estuary, and then become an important source of $\mathrm{N}$ for the planktonic community (Bronk et al. 2010). Alternatively, the chemical form of $\mathrm{N}$ species in LIS may have changed from inorganic to organic due to increasing abundances of mixotrophic phytoplankton, which has in turn altered $\mathrm{C}$ and $\mathrm{N}$ recycling. Positive correlations from this time series suggest the release of DON by Prasinophyceae and Cryptophyceae, which may occur due to death or predation by zooplankton. Studies have shown that labile DON, particularly amino acids and peptides, can be released by phytoplankton either by exudation of intact cells or viral lysis (e.g. Sarmento et al. 2013). Furthermore, concentrations of $\mathrm{NH}_{4}{ }^{+}$and labile DON tend to be elevated in the presence of suspension-feeding grazers (Taylor 1982, Ward \& Bronk 2001). Predation can therefore stimulate further production by regenerating both inorganic and organic $\mathrm{N}$ for use by both primary producers and heterotrophs. Unfortunately, long-term changes in predation, food-web interactions, and abundances of phytoplankton predators in LIS could not be determined from the available data. Additionally, alternate sources of DON to LIS, such as nonpoint sources, have not been considered here. Unfortunately, these sources are diffuse and difficult to measure, impairing $\mathrm{N}$ budget calculations.

As DON stocks increase in LIS, species that can use organic forms of $\mathrm{N}$ may have a competitive advantage. Phytoplankton, such as Prasinophyceae, Prymnesiophyceae, and dinoflagellates, have been shown to depend on DON as a source of $\mathrm{N}$ while diatoms generally have a higher affinity for DIN (Berman \& Bronk 2003, Taylor et al. 2006). For example, Aureococcus anophagefferens, an increasingly problematic bloom-forming pelagophyte in Long Island bays, 
has been shown to outcompete other taxa at low or moderate DON or $\mathrm{NH}_{4}{ }^{+}$concentrations (Taylor et al. 2006). In addition, dinoflagellates, Prymnesiophyceae, Prasinophyceae, and Cryptophyceae have been shown to switch between autotrophy and heterotrophy, and may also possess a competitive advantage as DON stocks increase (Caron 2000).

In western LIS, long-term declines in diatoms (indicated by BioSi) were coincident with declines in inorganic N loads. While average DIN concentrations have not declined below levels that are limiting for neritic diatoms (Eppley et al. 1969), lower average concentrations suggest that there are more frequent events of limitation for diatoms. For example, DIN concentrations were $<1.0 \mu \mathrm{M}$, the half-saturation constant for natural marine communities in eutrophic waters (MacIsaac \& Dugdale 1969), in 10 samples during the first 12 mo of analysis. During the last $12 \mathrm{mo}$, this occurred in 44 samples from all stations. In addition, we observed more frequent events in which diatoms were $<10 \%$ of the total community at the end of the observation period than at the beginning. Taken together, this suggests that the frequency of DIN-limitation events for diatoms increased throughout this record. Diatoms generally become limited by resource availability before smaller cells (Sunda \& Hardison 2007) and typically decline in response to declining DIN:DIP ratios, while other taxa, particularly dinoflagellates, may have competitive advantage under DIP-replete conditions (Lagus et al. 2004). DIN-limitation has also been shown to cause decreases in cellular organic N content (Harrison et al. 1977) and diminished chl a content in many species, including diatoms and dinoflagellates (Harrison et al. 1977, Henriksen et al. 2002). Therefore, in a system in which DIN:DIP ratios have declined, it is not surprising that the $\mathrm{N}$ and chl a content of planktonic biomass has changed and flagellated taxa have benefited.

Phosphate concentrations increased at all stations analyzed in this study. The main source of $\mathrm{PO}_{4}{ }^{3-}$ into western LIS is sewage discharge through the East River, which is largely derived from human waste (Sweeney \& Sañudo-Wilhelmy 2004). Since 1992, NYC has been adding ortho-phosphoric acid to municipal drinking water to inhibit leaching of lead from old plumbing (Maas et al. 2005), which likely contributed to increased DIP loadings into western LIS. Furthermore, some rivers throughout the northeastern US have also recently experienced rising $\mathrm{P}$ loadings, suggesting that LIS is being influenced by freshwater discharges (Trench et al. 2012). DIP is also released during organic matter remineralization in anoxic sediments, explaining the negative relationship between bottom water DO and P concentrations (Kemp et al. 2009). This process necessarily varies seasonally with hypoxic conditions in LIS. Therefore, the small declines in bottom water DO in western LIS may also have contributed to the long-term interannual increases in water-column DIP stocks. DIP pools may also be accumulating due to decreased productivity brought on by DIN-limitation. However, this study cannot assess changes in total productivity. Studies have also shown that slower-growing phytoplankton have a lower $\mathrm{P}$ requirement than fastergrowing phytoplankton due to the growth requirement of P-rich RNA (Arrigo 2005). The observed shift away from fast-growing P-rich diatoms may, in part, explain increased inventories of DIP. However, trends also indicate that particulate biomass became enriched in $\mathrm{P}$ relative to $\mathrm{N}$, which is inconsistent with a phytoplankton community requiring lower P levels. Alternatively, if the phytoplankton community shifted to one that is more dependent on organic sources of nutrients, DOP may have become an important source of $\mathrm{P}$, diminishing demands on DIP pools. However, no significant changes in DOP were identified.

Total Si pools also increased over the entire $15 \mathrm{yr}$ period, indicating that the source of Si to the estuary increased. This trend is consistent with recent studies in local rivers, including the CT River, which have also shown increases in $\mathrm{Si}$ loads in recent years (Latimer et al. 2014). Therefore, it is possible that this source of Si to LIS has increased over time, possibly due changes in weathering rates. Although diatom chl a concentrations were correlated with DSi concentrations on monthly timescales at Stn A4, DSi concentrations increased while diatoms declined on interannual timescales. Diatoms typically dominate LIS's spring blooms and can be limited by DSi in this system (Gobler et al. 2006). In many estuaries, diatoms decrease as the degree of eutrophication increases because they become limited by Si due to increasing N:Si ratios (Cloern 2001). However, in LIS, diatom abundances decreased as $\mathrm{N}$ loadings abated, indicating that DIN, instead of DSi, may be limiting for diatom production over interannual time scales. Declining diatom stocks and decreased demands for DSi may have therefore caused the accumulation of DSi in LIS.

\section{Shifting planktonic conditions in western LIS}

Several indicators of particulate biomass declined throughout this time series while chl a increased. At 
first sight, this suggests that photosynthetic biomass has increased and, in turn, detrital and heterotrophic planktonic biomass has decreased. However, while several of the planktonic biomass indicators (TSS, PC, PN, PP) certainly include a non-living fraction, these were all strongly correlated with fluctuations in diatom-chl $a$ and other phytoplankton taxa, suggesting that a large portion of the variability in these indicators was forced by changes in phytoplankton abundances. Furthermore, the increase in chl a concentrations that occurred in 2000 covaried with the BioSi and PP indicators, and steady declines in chl a throughout the entire the time series were coincident with declines in all other indicators. While many factors contribute to total suspended particulates in the water column, phytoplankton abundance seems to be a major contributor to this pool in LIS.

The anomalous jump in chl a concentrations evident in western LIS in 2000 coincided with falling temperatures and rising salinity and density conditions. Unfortunately, phytoplankton pigment data were not available until after 2002, precluding examination of evolving phytoplankton community structure during this transition. However, the pigment data can be used to retrospectively infer which groups may have been important during this period. Multivariate analyses showed that increases in biomass in 2000 covaried with enrichments in chl a-, Si-, and P-rich biomass. Post-2002, dinoflagellates, Prasinophyceae, and diatom biomass all covaried with changes in PP and BioSi, suggesting that these groups contributed to the increases in planktonic biomass during the rapid increase in chl $a$ in 2000.

While change-point analyses suggest that the increase in chl a concentrations in western LIS was a sudden change to a new condition, further evidence would be necessary in order to qualify this as an ecosystem-wide regime shift (Collie et al. 2004). In San Francisco Bay, it has been shown that increases in chl a concentrations during reductions in nutrient loadings were due to an oceanic regime change in the eastern North Pacific Ocean caused by increased rates of oceanic upwelling (Cloern et al. 2007). This induced a trophic cascade within the estuary (Cloern et al. 2007). In LIS, we cannot make inferences about changes to the food web due to lack of data, and therefore cannot determine whether changing chl a concentrations coincided with a regime change. However, interannual fluctuations in surface salinities and river discharge into LIS have previously been linked with shifts in the North Atlantic Oscilla- tion (Whitney 2010). While upwelling is not a factor in the western North Atlantic, the possibility of an ocean-estuary linkage cannot be discounted as a driver of the changes in LIS. Furthermore, studies in the North Atlantic provide evidence of long-term increases in dinoflagellates and declines in diatoms since the 1950s, suggesting that the changes observed in LIS may be part of a larger regional trend (Leterme et al. 2005).

Salinity and temperature regimes have previously been shown to select for various phytoplankton taxa. In some regions, Prasinophyceae and other picophytoplankton have been associated with warm, saline water masses while other species dominate under cooler, less saline conditions (Mostajir et al. 2001). Cryptophyceae have also been shown to dominate in the Neuse River Estuary during years of low salinity (Paerl et al. 2003) and in polar regions during years of high freshwater input (Mendes et al. 2013). In our study, Cryptophyceae covaried with all inorganic nutrients, suggesting that in LIS they are also positively associated with freshwater input. Individual dinoflagellate species have been shown to vary both positively and negatively in response to different salinity and temperature regimes (Zonneveld 1997). Furthermore, fluctuations in dominant taxa could be a naturally occurring cycle; in a multidecadal time series from nearby Narragansett Bay, diatom abundances were shown to oscillate on timescales of $5 \mathrm{yr}$ (Smayda 1998). Unfortunately, the LIS chl a dataset is too short to determine any natural fluctuations on these timescales.

After 2000, chl a stocks were above the long-term average but declining. Diatom abundances were declining during this period while dinoflagellates, Prymnesiophyceae, Cryptophyceae, Raphidophyceae, and Euglenophyceae were all increasing. Dinoflagellates and Prymnesiophyceae have lower chl a:C ratios than diatoms (Geider 1987). Therefore, in addition to declining abundances of diatoms, declining chl a stocks post-2000 can also be explained by shifts in community composition.

Analysis of the dynamics between the different phytoplankton taxa showed that Cryptophyceae and Raphidophyceae dominated when diatoms were in low abundance. Relationships among these groups may be controlled by competitive exclusion or other interactions, such as allelopathy, preferential grazing, or susceptibility to viral infection. For example, inhibitory interactions between Raphidophyceae and diatoms have previously been observed, likely due to allelopathy by both groups (Yamasaki et al. 2007). Furthermore, studies have shown that both copepods 
and microzooplankton preferentially graze on different size classes, and each can potentially be a topdown control on phytoplankton community structure in some systems (Lonsdale et al. 1996, Loder et al. 2011).

Fluctuations in diatom-chl $a$ at Stn A4 post-2002 positively correlated with salinity stratification. Traditionally, diatoms have been shown to proliferate when stratification breaks down, while other taxa, such as dinoflagellates, can utilize diel migrations, allowing them to outcompete diatoms under stratified conditions (Blasco 1978). However, water densities at Stn A4 are closely tied to sewage discharge from the East River, which is typically fresher and nutrient-rich relative to receiving waters (Buck et al. 2005). Therefore, N concentrations, stratification, and diatom abundances should all covary with fluctuations in discharge from WWTPs at A4. In addition, over the 15 yr time series, small decreases in stratification were detected. Therefore, although stratification did not covary with the increase in chl $a$ in 2000, long-term steady declines in stratification cannot be discounted as an explanation for long-term declining diatom abundances at A4.

\section{SUMMARY}

In summary, an abrupt increase in chl a concentrations, correlated to changes in temperature and salinity, was superimposed on a long-term declining trend of diatom abundances, likely driven by DIN limitation. Decreases in diatoms have not necessarily led to overall declines in total planktonic biomass or abatement of eutrophic conditions. Bottom water DO concentrations continued to decline in western LIS throughout this time series. Both surface and bottom water DO concentrations covaried positively with chl $a$ and negatively with temperature. These relationships were not surprising because DO is produced during photosynthesis and DO solubility varies inversely with temperatures. After 2002, declines in chl $a$ were driven by both shifts in community structure and changes in total planktonic biomass. These changes appear to be due to phytoplankton adaptation to evolving nutrient conditions, stemming from DIN deficiency relative to inorganic $\mathrm{P}$ and organic $\mathrm{N}$, as well as responses to changing temperature and salinity regimes.

A linkage between N, phytoplankton blooms, their decomposition, and summer hypoxia has been the central tenet of coastal eutrophication management for decades (Cloern 2001). Attempts by resource managers to reduce $\mathrm{N}$ in the Sound appear to be working, with significant reductions in DIN at nearly all of the monitoring stations, accompanied by a decrease in total diatom abundances. In general, diatoms are believed to contribute significantly to bottom water organic matter (Michaels \& Silver 1988). Thus it could be argued that diatoms have been the unintended major target of the total maximum daily loads of N. The DIN reductions, however, have not kept pace with DON or DIP increases, and thus TDN concentrations actually have increased over the $15 \mathrm{yr}$ time series. These results suggest that the phytoplankton assemblage as a whole has adapted by shifting to an assemblage of smaller cells that can more effectively compete for DIN at lower concentrations or can access the DON pool. Furthermore, this change may not necessarily decrease the amount of sinking organic matter to bottom waters; even picoplankton have been shown to aggregate and contribute to sinking biomass (Wilson \& Steinberg 2010).

These results explain in part why the frequency, duration, and intensity of hypoxia in LIS have not lessened with reductions of DIN. An immediate reduction in hypoxia concomitant with reductions in $\mathrm{N}$ seems unlikely given the complexity of this system and the likelihood that the sediments are a large nutrient reservoir, releasing $\mathrm{N}, \mathrm{P}$, and $\mathrm{Si}$ over time. However, we do not question the value of $\mathrm{N}$ reduction programs because system response times probably exceed the duration of our observations. Both DIN concentrations and primary productivity at Stn A4 remain high, and western LIS is still very eutrophic (Goebel et al. 2006). A eutrophic estuary, particularly one impacted by human activities for several hundred years, is clearly out of balance with its natural state. Investigation of processes that could optimize the return to a less impacted condition should be given priority in hypoxia research.

Acknowledgements. We thank NY Sea Grant and LISS for their support of the project through grant nos. R/CMB-35NYCT and R/CMB-36-NYCT and support of E.A.S. through the NY Sea Grant Scholars program. In addition, we thank the CTDEEP for collection and maintenance of an invaluable dataset, the NYDEC for discharge data, the NY/NJ/CT Interstate Environmental Commission for monthly operating reports from individual plants, and anonymous reviewers for their thoughtful comments of earlier drafts. Finally, we are grateful to S. Hameed and R. E. Wilson (Stony Brook University) for assistance with data analyses and interpretation. This is School of Marine and Atmospheric Sciences contribution 1422 . 


\section{LITERATURE CITED}

Anderson TH, Taylor GT (2001) Nutrient pulses, plankton blooms, and seasonal hypoxia in western Long Island Sound. Estuaries 24:228-243

Arrigo KR (2005) Marine microorganisms and global nutrient cycles. Nature 437:349-355

> Barnett TP, Preisendorfer R (1987) Origins and levels of monthly and seasonal forecast skill for United States surface air temperatures determined by canonical correlation analysis. Mon Weather Rev 115:1825-1850

- Berman T, Bronk DA (2003) Dissolved organic nitrogen: a dynamic participant in aquatic ecosystems. Aquat Microb Ecol 31:279-305

$>$ Blasco D (1978) Observations on the diel migrations of marine dinoflagellates off the Baja California coast. Mar Biol 46:41-47

- Bronk DA, Roberts QN, Sanderson MP, Canuel EA and others (2010) Effluent organic nitrogen (EON): bioavailability and photochemical and salinity-mediated release. Environ Sci Technol 44:5830-5835

Buck NJ, Gobler CJ, Sañudo-Wilhelmy SA (2005) Dissolved trace element concentrations in the East River-Long Island Sound system: relative importance of autochthonous versus allochthonous sources. Environ Sci Technol 39:3528-3537

Caron D (2000) Symbiosis and mixotrophy among pelagic microorganisms. In: Kirchman D (ed) Microbial ecology of the oceans. Wiley-Liss, New York, NY, p 495-523

$>$ Cloern JE (2001) Our evolving conceptual model of the coastal eutrophication problem. Mar Ecol Prog Ser 210: 223-253

Cloern JE, Jassby AD, Thompson JK, Hieb KA (2007) A cold phase of the East Pacific triggers new phytoplankton blooms in San Francisco Bay. Proc Natl Acad Sci USA 104:18561-18565

Collie JS, Richardson K, Steele JH (2004) Regime shifts: Can ecological theory illuminate the mechanisms? Prog Oceanogr 60:281-302

Conley DJ, Paerl HW, Howarth RW, Boesch DF and others (2009) Controlling eutrophication: nitrogen and phosphorus. Science 323:1014-1015

- Diaz RJ, Rosenberg R (2008) Spreading dead zones and consequences for marine ecosystems. Science 321:926-929

Eppley RW, Rogers JN, McCarthy JJ (1969) Half-saturation constants for uptake of nitrate and ammonium by marine phytoplankton. Limnol Oceanogr 14:912-920

> Geider RJ (1987) Light and temperature dependence of the carbon to chlorophyll-a ratio in microalgae and cyanobacteria-implications for physiology and growth of phytoplankton. New Phytol 106:1-34

- Gobler CJ, Buck NJ, Sieracki ME, Sañudo-Wilhelmy SA (2006) Nitrogen and silicon limitation of phytoplankton communities across an urban estuary: the East River-Long Island Sound system. Estuar Coast Shelf Sci 68:127-138

> Goebel NL, Kremer JN, Edwards CA (2006) Primary production in Long Island Sound. Estuaries Coasts 29:232-245

> Gruber N, Sarmiento JL (1997) Global patterns of marine nitrogen fixation and denitrification. Global Biogeochem Cycles 11:235-266

Hansell DA, Bates NR, Olson DB (2004) Excess nitrate and nitrogen fixation in the North Atlantic Ocean. Mar Chem 84:243-265

- Harrison PJ, Conway HL, Holmes RW, Davis CO (1977) Marine diatoms grown in chemostats under silicate or ammo- nium limitation. 3. Cellular chemical composition and morphology of Chaetoceros debilis, Skeletonema costatum, and Thalassiosira gravida. Mar Biol 43:19-31

- Henriksen P, Riemann B, Kaas H, Sorensen HM, Sorensen HL (2002) Effects of nutrient-limitation and irradiance on marine phytoplankton pigments. J Plankton Res 24: 835-858

Howarth RW, Marino R (2006) Nitrogen as the limiting nutrient for eutrophication in coastal marine ecosystems: evolving views over three decades. Limnol Oceanogr 51: 364-376

> Howell P, Simpson D (1994) Abundance of marine resources in relation to dissolved oxygen in Long Island Sound. Estuaries 17:394-402

> Irigoien X, Meyer B, Harris R, Harbour D (2004) Using HPLC pigment analysis to investigate phytoplankton taxonomy: the importance of knowing your species. Helgol Mar Res 58:77-82

Kemp WM, Testa JM, Conley DJ, Gilbert D, Hagy JD (2009) Temporal responses of coastal hypoxia to nutrient loading and physical controls. Biogeosciences 6:2985-3008

> Lagus A, Suomela J, Weithoff G, Heikkila K, Helminen H, Sipura J (2004) Species-specific differences in phytoplankton responses to $\mathrm{N}$ and $\mathrm{P}$ enrichments and the $\mathrm{N}: \mathrm{P}$ ratio in the Archipelago Sea, northern Baltic Sea. J Plankton Res 26:779-798

Latimer JS, Tedesco MA, Swanson RL, Yarish C, Stacey PE, Garza C (eds) (2014) Long Island Sound: prospects for the urban sea. Springer, New York, NY

> Lee YJ, Lwiza KMM (2005) Interannual variability of temperature and salinity in shallow water: Long Island Sound, New York. J Geophys Res 110:C09022, doi:10. 1029/2004JC002507

Lee YJ, Lwiza KMM (2008) Characteristics of bottom dissolved oxygen in Long Island Sound, New York. Estuar Coast Shelf Sci 28:1352-1362

Leterme SC, Edwards M, Seuront L, Attrill MJ, Reid PC, John AWG (2005) Decadal basin-scale changes in diatoms, dinoflagellates, and phytoplankton color across the North Atlantic. Limnol Oceanogr 50:1244-1253

> Levine SN, Schindler DW (1999) Influence of nitrogen to phosphorus supply ratios and physicochemical conditions on cyanobacteria and phytoplankton species composition in the Experimental Lakes Area, Canada. Can J Fish Aquat Sci 56:451-466

Li Y, Olsen CB, Lyman MJ, Van Heukelem L, Wikfors GH, Miranda L, Lin S (2004) Monitoring phytoplankton in Long Island Sound with HPLC photopigment profiles. In: McNamara S (ed) Long Island Sound Research Conference Proceedings. Long Island Sound Foundation, University of Connecticut, Storrs, CT, p 45-52

LISS (Long Island Sound Study) (2011) Protection and progress: Long Island Sound Study biennial report 2009-2010. Available at www.longislandsoundstudy.net (accessed 25 March 2013)

> Llewellyn CA, Fishwick JR, Blackford JC (2005) Phytoplankton community assemblage in the English Channel: a comparison using chlorophyll a derived from HPLC-CHEMTAX and carbon derived from microscopy cell counts. J Plankton Res 27:103-119

- Loder MGJ, Meunier C, Wiltshire KH, Boersma M, Aberle N (2011) The role of ciliates, heterotrophic dinoflagellates and copepods in structuring spring planktonic communities at Helgoland Roads, North Sea. Mar Biol 158: $1551-1580$ 
Lonsdale DJ, Cosper EM, Doall M (1996) Effects of zooplankton grazing on phytoplankton size-structure and biomass in the lower Hudson River Estuary. Estuaries 19: 874-889

Maas RP, Patch SC, Morgan DM, Pandolfo TJ (2005) Reducing lead exposure from drinking water: recent history and current status. Public Health Rep 120:316-321

> MacIsaac JJ, Dugdale RC (1969) The kinetics of nitrate and ammonia uptake by natural populations of marine phytoplankton. Deep-Sea Res Oceanogr Abstr 16:45-57

Mendes CRB, Tavano VM, Leal MC, de Souza MS, Brotas V, Garcia CAE (2013) Shifts in the dominance between diatoms and cryptophytes during three late summers in the Bransfield Strait (Antarctic Peninsula). Polar Biol 36: 537-547

Michaels AF, Silver MW (1988) Primary production, sinking fluxes and the microbial food web. Deep-Sea Res A 35: 473-490

Moron V, Robertson AW, Ward MN (2006) Seasonal predictability and spatial coherence of rainfall characteristics in the tropical setting of Senegal. Mon Weather Rev 134:3248-3262

- Mostajir B, Gosselin M, Gratton Y, Booth A and others (2001) Surface water distribution of pico- and nanophytoplankton in relation to two distinctive water masses in the North Water, northern Baffin Bay, during fall. Aquat Microb Ecol 23:205-212

Nixon S (1995) Coastal marine eutrophication: a definition, social causes, and future concerns. Ophelia 41:199-219

NYSDEC, CTDEEP (New York State Department of Environmental Conservation, Connecticut Department of Energy and Environmental Protection) (2000) A total maximum daily load analysis to achieve water quality standards for dissolved oxygen in Long Island Sound. Available at www.longislandsoundstudy.net (accessed 25 March 2013)

Paerl HW, Valdes LM, Pinckney JL, Piehler MF, Dyble J, Moisander PH (2003) Phytoplankton photopigments as indicators of estuarine and coastal eutrophication. Bioscience 53:953-964

Parker CA, O'Reilly JE (1991) Oxygen depletion in Long Island Sound: a historical perspective. Estuaries 14:248-264

Pettitt AN (1980) A simple cumulative sum type statistic for the change-point problem with zero-one observations. Biometrika 67:79-84

Sarmento H, Romera-Castillo C, Pinhassi J, Marrasé C, Taylor GT, Gasol JM (2013) Characterization of the bacterial community involved in the degradation of organic matter derived from phytoplankton. Limnol Oceanogr 58:1123-1135

Smayda TJ (1998) Patterns of variability characterizing marine phytoplankton, with examples from Narragansett Bay. ICES J Mar Sci 55:562-573

Smith SV, Swaney DP, Talaue-McManus L, Bartley JD and others (2003) Humans, hydrology, and the distribution of

Editorial responsibility: Steven Lohrenz,

New Bedford, Massachusetts, USA inorganic nutrient loading to the ocean. Bioscience 53: 235-245

Sunda WG, Hardison DR (2007) Ammonium uptake and growth limitation in marine phytoplankton. Limnol Oceanogr 52:2496-2506

Sweeney A, Sañudo-Wilhelmy SA (2004) Dissolved metal contamination in the East River-Long Island Sound system: potential biological effects. Mar Pollut Bull 48: 663-670

Taylor GT (1982) The role of pelagic protozoa in nutrient cycling: a review. Ann Inst Oceanogr 58(Suppl):227-241

Taylor GT, Gobler CJ, Sañudo-Wilhelmy SA (2006) Speciation and concentrations of dissolved nitrogen as determinants of brown tide Aureococcus anophagefferens bloom initiation. Mar Ecol Prog Ser 312:67-83

Trench ECT, Moore RB, Ehearn EA, Mullaney JR, Hickman E, Schwarz GE (2012) Nutrient concentrations and loads in the northeastern United States - Status and trends, 1975-2003. US Geological Survey Scientific Investigations Report 2011-5114. Available at http://pubs.usgs. gov/sir/2011/5114 (accessed 12 June 2013)

> Turekian KK, Tanaka N, Turekian VC, Torgersen T, Deangelo EC (1996) Transfer rates of dissolved tracers through estuaries based on ${ }^{228} \mathrm{Ra}$ : a study of Long Island Sound. Cont Shelf Res 16:863-873

Ward BB, Bronk DA (2001) Net nitrogen uptake and DON release in surface waters: importance of trophic interactions implied from size fractionation experiments. Mar Ecol Prog Ser 219:11-24

- Whitney MW (2010) A study on river discharge and salinity variability in the Middle Atlantic Bight and Long Island Sound. Cont Shelf Res 30:305-318

- Wilcox RR (1994) The percentage bend correlation coefficient. Psychometrika 59:601-616

Wilcox RR (2005) Robust regression. In: Holland BA, Singer $\mathrm{T}$ (eds) Introduction to robust estimation and hypothesis testing. Elsevier Academic Press, Waltham, MA, p 471-532

Wilks DS (2006) Canonical correlation analysis. In: Helé J (ed) Statistical methods in the atmospheric sciences. Elsevier Academic Press, Waltham, MA, p 509-528

Wilson SE, Steinberg DK (2010) Autotrophic picoplankton in mesozooplankton guts: evidence of aggregate feeding in the mesopelagic zone and export of small phytoplankton. Mar Ecol Prog Ser 412:11-27

Yamasaki Y, Nagasoe S, Matsubara T, Shikata T, Shimasaki Y, Oshima Y, Honjo T (2007) Allelopathic interactions between the bacillariophyte Skeletonema costatum and the raphidophyte Heterosigma akashiwo. Mar Ecol Prog Ser 339:83-92

Zonneveld KAF (1997) Dinoflagellate cyst distribution in surface sediments from the Arabian Sea (northwestern Indian Ocean) in relation to temperature and salinity gradients in the upper water column. Deep-Sea Res II 44: 1411-1443

Submitted: April 10, 2013; Accepted: October 12, 2013 Proofs received from author(s): January 6, 2014 